\title{
Governance of supplier collaboration in technologically uncertain NPD projects
}

\author{
Lisa Melander and Nicolette Lakemond
}

\section{Linköping University Post Print}

\section{Tweet}

N.B.: When citing this work, cite the original article.

Original Publication:

Lisa Melander and Nicolette Lakemond, Governance of supplier collaboration in technologically uncertain NPD projects, 2015, Industrial Marketing Management, (49), 116127.

http://dx.doi.org/10.1016/j.indmarman.2015.04.006

Copyright: Elsevier

http://www.elsevier.com/

Postprint available at: Linköping University Electronic Press

http://urn.kb.se/resolve?urn=urn:nbn:se:liu:diva-114890 
Date of original submission: July $4^{\text {th }} 2013$

Date of resubmission: March 5th 2014

Date of re-resubmission: January $28^{\text {th }} 2015$

\section{Governance of supplier collaboration in technologically uncertain NPD projects}

\section{Lisa Melander ${ }^{1}$ and Nicolette Lakemond ${ }^{2}$}

${ }^{1}$ Linköping University, Department of Management and Engineering

SE-581 83 Linköping, Sweden, +46 (0) 70-385 69 35, lisa.melander@afconsult.com

${ }^{2}$ Linköping University, Department of Management and Engineering, KITE Research Group

SE-581 83 Linköping, Sweden, nicolette.lakemond@liu.se 
Lisa Melander has a PhD from Linköping University, Sweden, and today she works at the consultancy firm $\AA \mathrm{F}$ in Gothenburg. Her research interests include new product development, innovation management, supplier management and digitalization. She has publications in journals such as Journal of Engineering and Technology Management and Supply Chain Management: an International Journal.

Nicolette Lakemond is Associate Professor and head of the division Project, Innovations and Entrepreneurship (PIE) at the department of Management and Engineering, Linköping University in Sweden. She is a member of the KITE research group, focusing on the study of innovation and knowledge integration in internationally competing industries. Key research interests revolve around the management of innovation, in particular the organization of innovation in open and collaborative settings. She has published in international journals such as Technovation, R\&D Management, Industrial Marketing Management, Journal of Purchasing and Supply Management, and Research Technology Management. 
Research highlights

- The attributes of TCE, particularly asset specificity and uncertainty, warrant governance of supplier involvement in NPD

- Governance of suppliers in NPD include both transactional and relational aspects

- Firms use limiting supplier involvement and increased levels of collaboration as governance strategies simultaneously

- Transactional and relational governance issues are separated in different organizational entities

- Purchasing and R\&D fulfill complementary roles in achieving transactional and relational governance in collaborative NPD 


\begin{abstract}
Firms that are searching for new technologies from suppliers through collaborative new product development (NPD) need to devise effective approaches for governing the supplier relationship. Based on in-depth case studies of four collaborative NPD projects, this paper shows that in projects with a high degree of uncertainty (1) firms achieve governance by simultaneously limiting supplier involvement and allowing for high levels of collaboration, (2) transactional and relational governance have distinct roles in achieving limited supplier involvement and establishing high levels of collaboration, and (3) transactional and relational governance are organizationally separated. These findings have implications for the complementary use of relational and transactional governance, as well as for the role of purchasing and R\&D in technologically uncertain NPD projects.
\end{abstract}

Keywords: New Product Development; Uncertainty; Governance; Supplier Collaboration; Transactional; Relational 
IMM Manuscript 13-158RR

\section{Introduction}

“Don't mix up business and collaboration. You need to be both friends and enemies in the right situation. We are enemies when prices are discussed and friends when we discuss technology." This quote represents a common challenge for today's firms that collaborate with their suppliers in new product development (NPD) projects. On the one hand, in a global environment characterized by fast technological advancement and a broad spectrum of different technologies, it is difficult for firms to maintain all technological expertise in-house. This necessitates collaboration with external organizations such as suppliers (Un, et al. 2010). The advantages of collaborating with suppliers have been demonstrated in previous research, where benefits include flexibility (Riege 2003), speed (Brown \& Eisenhardt 1995; Langerak \& Hultink 2008), improved innovation (Lau, et al. 2010), access to market information (Miotti \& Sachwald 2003), and access to the supplier's capabilities (Oh \& Rhee 2010). On the other hand, in order to achieve these benefits, it is crucial to recognize what the above quote represents; collaboration involves being friends as well as enemies at the same time. This stipulates the importance of governance of the relationship with suppliers. Governance spans contractual arrangements as well as establishing trust and shared goals. These represent transactional as well as relational mechanisms (Poppo \& Zenger 2002). Previous research clearly points at the complementarity role of transactional and relational governance (Blomqvist, et al. 2005; Cannon, et al. 2000; Liu, et al. 2009). However, studies have yet to explain how firms rely on an effective combination of transactional and relational governance. Both purchasing and R\&D could potentially fulfil an important role in governing supplier involvement in NPD (Olausson, et al. 2009), but there is a lack of empirical evidence regarding the extent to which R\&D engineers, along with purchasers, 
take on responsibility for relational and transactional governance, and how firms organize for complementary governance in projects with a high degree of technological uncertainty.

In order to address this, the purpose of this study is to explain how firms achieve complementarity of transactional and relational governance in collaborative, technologically uncertain NPD projects. In this paper, “collaborative projects” denote a situation where the buyer and the supplier develop a product together. We use the definition from Griffith, et al. to denote supplier collaboration in NPD projects, as “the degree to which the supplier influences a buyer's product designs and pre-development decisions" (2009 p. 221). Our study focuses on projects with a high degree of technological uncertainty, i.e. involving uncertainties about the outcomes of technology development and about the most suitable technology to be used. A high degree of technological uncertainty is considered to be a complicating factor in collaborative NPD projects as project outcomes cannot be predicted easily (Melander \& Tell 2014).

By using transaction cost theory (TCE) and based on in-depth case studies of four collaborative NPD projects, the paper shows that organizational separation of relational and transactional governance issues is commonly used to achieve complementarity in technologically uncertain, collaborative NPD projects. By separating transactional and relational governance issues across different organizational entities, a firm can avoid risking trustworthy relationships between key individuals in R\&D that are highly involved in the development of the new solution. The results show that R\&D engineers play an important role in relational governance, while purchasing but also the project steering committees have an important role in transactional governance. We propose that this pattern of organizational separation of transactional and relational governance is mainly prevalent in projects with a high degree of uncertainty. In projects with a lower degree of uncertainty more integrated approaches can be used through a 
IMM Manuscript 13-158RR

concerted effort of R\&D and purchasing. These findings have implications for the complementary use of relational and transactional governance, as well as for the role of purchasing in technologically uncertain NPD projects.

The paper is structured as follows. The following section outlines our theoretical framework, including the research propositions that are central in the study. The methodology and design of the empirical case studies are then described. Subsequently, empirical data about the four projects, including a cross-case analysis, are presented. This reveals patterns of organizational separation of relational and transactional governance under technological uncertainty and tradeoffs in responses to common TCE problems. Finally, conclusions, limitations of this study, and suggestions for future research are presented.

\section{Governance of collaborative projects}

\subsection{Determining prerequisites for governance-TCE theory}

The governance of knowledge and assets has long been a focus in different theories of the firm. Particularly transaction cost economics (TCE) addresses the governance of activities and transactions across firm boundaries (Jagdev \& Thoben 2001). In this context, governance refers to the mechanisms that are used for coordination and control of exchanges (Mahapatra, et al. 2010). The use of TCE theory is common in the field of marketing and the theory is mainly used to explain why firms choose certain modes of governance to handle transactions (David \& Han 2004; John \& Reve 2010; Williamson \& Ghani 2012). These governance modes are connected to three types of governance problems, i.e. problems related to safeguarding for opportunistic behavior, adaptation to changes in the environment, and performance evaluation to diminish behavioral uncertainty (Rindfleisch \& Heide 1997). Generally, if the costs related to these 
problems are high, firms are more likely to opt for governance approaches that allow for monitoring, long-term rewards and socialization processes, rather than market governance. In the context of customer-supplier relationships, according to TCE, the principal attributes of transactions are related to transaction specific investments, the uncertainty arising from buyerbounded rationality and supplier opportunism, and the frequency of transactions (David \& Han 2004; Griffith, et al. 2009; Williamson \& Ghani 2012).

Transaction specific investments are made when a firm has little or no use of the assets outside of a specific relationship (Williamson 1985). This causes a safeguarding problem as the specificity of the asset for a particular transaction may cause a fear that the other firm behaves opportunistically and exploits these investments. Overall, TCE predicts that high levels of asset specificity push transactions into more integrated forms of governance (David \& Han 2004). However, in a context of collaborative NPD, asset specificity has been associated with increased levels as well as decreased levels of collaboration (Griffith, et al. 2009). More specifically, two sources of asset specificity, i.e. a high degree of modularity and high strategic value of the project are found in combination with increased supplier involvement. In these situations increased levels of involvement can diminish the transaction risk through increased levels of social control (Heide \& John 1992). In contrast, high technological specificity, as a third source of asset specificity, is related to lower levels of supplier involvement, especially under circumstances of technological uncertainty. Consequently, increased levels and decreased levels of collaboration can both be appropriate.

A second attribute of transactions, the degree of uncertainty, refers to unanticipated changes that concern the transaction (Williamson 1985). Uncertainty is specifically related to constraints of cognitive capabilities and bounded rationality (Rindfleisch \& Heide 1997). In collaborative 
NPD projects, customers have a limited cognitive ability that reduces their possibilities to predict the behavior of their suppliers. This creates problems in verifying compliance in existing agreements, and entails difficulties in specifying all future contingencies in a contract (Griffith, et al. 2009). The inability to verify compliance is related to performance measurement problems, while difficulties in foreseeing future contingencies represent an adaptability problem (John \& Reve 2010). In general, responses to these problems would warrant governance based on either diminishing dependencies, e.g. through market governance, or increasing vertical integration by pushing transactions into hierarchy (David \& Han 2004). Under circumstances of high technological uncertainty, customer firms may choose to opt for a prospective but not fully proven technology expected to outperform existing, proven technologies (Krishnan \& Bhattacharya 2002). Some previous studies indicate that in these circumstances, lower levels of supplier involvement are common (Griffith, et al. 2009). However, other studies suggest that vertical integration and non-market controlling mechanisms are appropriate to foster closer relationships with suppliers (Bensaou 1999; Dyer 1997; Petersen, et al. 2003). Consequently, responses to uncertainty also point in two possible but opposite responses building on limiting supplier involvement as well as increased levels of collaboration.

While asset specificity and uncertainty have been thoroughly examined in studies building on TCE, a third attribute, frequency of transactions, has not been in focus to the same extent (David \& Han 2004). TCE theory predicts that an increase in frequency would move the exchange from markets into hierarchies, as frequent transactions require constant monitoring (Williamson 1985). Furthermore, in collaborative NPD projects, the frequency of transactions is important in relation to the behavioral aspects of governance, such as trust, and enhances the possibilities to work integrated (Rosell, et al. 2014). 
IMM Manuscript 13-158RR

The discussion related to the three attributes of TCE in relation to appropriate directions for governance of collaborative NPD projects clearly points in two different directions. On the one hand, limiting supplier involvement is an accurate response to asset specificity and uncertainty. On the other hand, these same attributes could also stipulate governance based on increased levels collaboration. Consequently, the following proposition is formulated:

Proposition 1: The attributes of TCE, particularly asset specificity and uncertainty, warrant responses based on limiting supplier involvement as well as increased levels of collaboration.

\subsection{Transactional and relational governance}

Proposition 1 above represents an unclear and somewhat contradictory advice for firms that want to implement appropriate governance of collaborative NPD projects. It seems that both limiting and increased levels of collaboration are appropriate responses. Firms may handle this contradiction by relying on complementary, but different mechanisms. These include transactional mechanisms such as specific contracts, IP agreements and sometimes even specific investments (Arranz \& de Arroyabe 2012; Burkert, et al. 2012; Jap \& Ganesan 2000) and relational mechanisms such as trust, frequent transactions and shared goals (Poppo, et al. 2008).

Transactional governance mechanisms are commonly used in buyer-supplier relationships (Yu, et al. 2006). Contracts can be used with any partner, including new and old acquaintances. A contract defines responsibilities, measures compliance and establishes compensation (Baldwin 2008). Recent studies show that contracts can also be used as coordination mechanisms (Lumineau \& Henderson 2012) and to govern complex transactions where firms apply joint problem solving (Argyres \& Mayer 2007). Contracts can be used ex ante, i.e. in connection with selection or information-gathering, and ex post, in connection with measurement and 
enforcement (Rindfleisch \& Heide 1997). This study focuses on the ex-ante part of contracting, which involves drafting, negotiating and safeguarding the contract (Williamson 1985).

Several advantages of contracts have been highlighted; contracts can create a ground for mutual understanding and commitments in collaborative NPD projects, coordinate agreements on intellectual property rights, and result in specific investments (Blomqvist, et al. 2005; Burkert, et al. 2012). Therefore, complex customized contracts can be considered as a hybrid form of governance suited for higher degrees asset specificity (Jagdev \& Thoben 2001). Studies of NPD collaborations also point to disadvantages of having too-specific contracts and agreements, as these tend to reduce flexibility in projects (Håkanson 1993). Furthermore, in NPD characterized by uncertainty, it may not be possible to specify everything beforehand and firms may find it difficult to modify contracts during a project (John \& Reve 2010; Rindfleisch \& Heide 1997). This results in an adaptation problem, and clearly points at the limitations of transactional governance through contracts or agreements.

In addition to contracts, relational governance based on close and enduring interorganizational relationships have been proposed as a hybrid form of governance (Rindfleisch \& Heide 1997). Relational governance often results in close relationships and the establishment of social norms. These can be used as a means of safeguarding specific investments and adapting to uncertainty (Heide \& John 1990; Mahapatra, et al. 2010). In contrast to contracts, relational governance takes time to establish.

Previous studies of buyer-supplier collaborations show that trust is an important mechanism in relational governance (Claro, et al. 2003). Trust and commitment enable openness and understanding (Ritter \& Walter 2003). The mechanism of trust is not easily defined, and encompasses consistency, competence, benevolence, honesty, and openness (Adler 2001). In 
collaborations, it is suggested that each party should be trustworthy, meaning that they should keep promises, be frank and demonstrate integrity (Rampersad, et al. 2010). In order to use trust as a mechanism for governance, the parties involved must have a personal relationship of long standing (Poppo \& Zenger 2002). Consequently, firms may be inclined to integrate previous collaboration partners into projects for future generations of NPD. Such repeated trust-based relationships with key suppliers allow the customer firm to access complementary capabilities and specialized knowledge (Lorenzoni \& Lipparini 1999). Besides trust and frequent transactions, several studies point to the importance of goal alignment (Dayan \& Basarir 2009; Handfield \& Lawson 2007; Rossetti \& Choi 2008; Wagner \& Hoegl 2006). Goal alignment can also be considered as a non-economic, sociological factor that prescribes the expectations of behaviors in the relationship. These are central in relational governance (Granovetter 1985; Heide \& John 1992; Ring \& Van De Ven 1994). This type of governance is particularly important in circumstances of technological uncertainty (Zhou, et al. 2008), and seems to facilitate high degrees of tacit knowledge exchange (Arranz \& de Arroyabe 2012).

Previous research has found that relational and transactional mechanisms can be used separately or as complements to each other (Blomqvist, et al. 2005; Liu, et al. 2009). There is evidence for the positive effects of the complementarity of the two types of mechanisms (Cannon, et al. 2000). For instance, when complex and innovative products are developed, it may be difficult to formulate complete contracts. Yet, the risks related to information asymmetry (when the supplier knows more than the customer), asset obsolescence (when specific investments are made), and switching costs to shift business to alternative suppliers are high (Mahapatra, et al. 2010). In these situations, the role of relational governance as a complement and/or substitute for transactional governance increases (Arranz and de Arroyabe 2012; Cannon, 
et al. 2000; Zhou, et al. 2008). Consequently, previous research has shown that transactional and relational governance mechanisms are applied simultaneously. In this paper we suggest that they may fulfill different roles in achieving responses building on limiting and increased level of collaboration as proposed in proposition 1. This leads to the following proposition:

Proposition 2: Transactional and relational governance fulfill complementary roles in simultaneously achieving limiting supplier involvement and increased levels of collaboration

\subsection{Who takes care of governance? - The role of purchasing and $R \& D$}

The organization of governance is not trivial in organizations, and it has been argued that purchasing, together with $R \& D$ and production, fulfils an important role in the coordination of the NPD (van Echtelt, et al. 2008). With the growing realization that purchasing has a significant influence on a firm's bottom line, scholars have argued that purchasing has an important and maybe even dominant role in transactional as well as relational governance. Traditionally, the purchasing function has been a primary concern when closing a deal with a supplier and preparing contracts (Burt \& Soukup 1985). This perspective on the purchasing function is based on the fact that purchasing manages input, ensures that these are delivered on time, are of sufficient quality, and are at an acceptable price (Burt \& Soukup 1985). However, with purchasing's increasing importance, it has been argued that purchasing gains an additional role as relationship managers that create trust. Schiele (2010) refers to the dual role of purchasing, adding an innovation-orientation to the traditional cost-orientation of purchasing activities. An innovation-orientation concerns aligning internal development activities with the development activities of suppliers, including ensuring that the supplier's technical competencies are exploited, and committing the supplier's activities to the NPD project (Wynstra, et al. 2003). 
Purchasing's roles in NPD have been divided into project involvement, interface management, operational activities and monitoring (Nijssen, et al. 2002).

Although purchasing has received a lot of attention, some studies show that the role of purchasing in governing supplier relationships in collaborative NPD projects are more limited than expressed in literature on the subject. It might be that purchasing professionals overestimate their importance in relation to other actors (Tassabehji \& Moorhouse 2008). Contrary to purchasing professionals, $R \& D$ engineers, $R \& D$ managers and project managers may work together with supplier engineers on a day-to-day basis in collaborative NPD projects and may therefore play a central role in knowledge exchanges with suppliers (Thomas 2013; Wagner \& Hoegl 2006). Studies of collaborative NPD projects have shown that R\&D engineers build trustful relationships with supplier engineers in order to facilitate knowledge integration and joint learning (Rosell, et al. 2014). Therefore, it may be that purchasing professionals and R\&D engineers have distinct roles in the governance of collaborative NPD projects (Brattström \& Richtnér 2013). These roles may be designed to achieve transactional as well as relational governance in different situations and related to different activities, and also to be able to limit supplier involvement on certain issues, but achieve extensive collaboration on others. Based on this, the following proposition is formulated:

Proposition 3: Purchasing and R\&D fulfill complementary roles in achieving transactional and relational governance in collaborative NPD

\section{Methodology}

The empirical evidence on how complementarity of transactional and relational governance is achieved and the role of R\&D and purchasing in establishing governance and the level of 
collaboration is based on case studies of four collaborative NPD projects at a single firm. We refer to this firm by the pseudonym "Voltcomp". Voltcomp is a high-tech system integrator and experienced in collaborating with external suppliers that are widely acknowledged for their innovative capabilities and make considerable investments in R\&D. We refer to these suppliers as technology suppliers. The studies were conducted in a high-tech industry because firms operating in such industries generally tend to be involved in more R\&D partnerships (Hagedoorn 2002) and are more likely to collaborate with technology suppliers. The case sampling strategy consisted of sampling information-rich cases that were suitable for making comparisons. All projects were sampled with the aim of being useful for illustrating supplier collaboration in NPD (Siggelkow 2007). The projects involved technology that was new to Voltcomp and was provided by external suppliers. We selected three particular projects that had high technological uncertainty according to key informants at the firm: the battery project, the storage project and the cable project. All three projects concerned high-voltage applications and uncertainty in the projects was largely related to the question whether the suppliers' technologies could be applied in high-voltage contexts. In addition, we selected a fourth project, the hybrid project, with considerably lower uncertainty. This project was also a high voltage application, but focused on the development of a product based on a supplier technology that had already been used in this type of applications. In our research design, the fourth project was used to identify possible differences of relational and transactional governance in comparison to the three technologically uncertain projects. The classification of projects is shown in Figure 1.

\begin{tabular}{|c|c|}
\hline \multicolumn{2}{|c|}{ Technological uncertainty related to high-voltage applications } \\
High
\end{tabular}

Fig. 1. Project selection 
IMM Manuscript 13-158RR

The data collection consisted of three phases, which allowed data triangulation. First a document study was performed; thereafter interviews with knowledgeable respondents were conducted, and finally a workshop was performed. The document study focused on the industry context of the focal firm and was based on specific company information, industry information, and financial data. The main data consists of 31 semi-structured interviews with employees at Voltcomp and its suppliers. Interviews have been described as a highly efficient method to gather detailed empirical data (Eisenhardt \& Graebner 2007). In the interview study, the sampling of respondents consisted of individuals with different responsibilities in order to diminish common source bias and allow for data triangulation across multiple sources (Beverland \& Lindgreen 2010; Piekkari, et al. 2010; Wagner 2012). This supported our aim to provide a wider perspective of the collaborative NPD projects and the role of purchasing and R\&D in governing the supplier relationship. The design of this study allows the investigation of purchasing and R\&D's role in collaborative and technologically uncertain NPD projects that are carried out together with suppliers. All individuals were identified as being knowledgeable respondents by our contact person at the firm. Some of the interview respondents were identified at the outset of the study, but other additional respondents were identified during the interviews. More specifically, we relied on information from project members, $R \& D$ managers, purchasing managers, decision makers, marketing managers and technical experts. All respondents had technical backgrounds, including the purchasers, with a minimum of a Master's degree in engineering. The projects involved members with similar roles, but the members' specific job titles varied across the projects, which is reflected in the overview of respondents by their job titles in Table 1. Nonetheless, similar information from similar perspectives was gathered for all projects. It should be noted that the R\&D manager for the battery project was also the manager 
for the storage project. During one interview, the R\&D manager answered questions about both projects.

We used the diverse perspectives of the respondents to gain a more reliable picture and to confirm findings from one perspective with other perspectives (Eisenhardt \& Graebner 2007). All the interviews were semi-structured, which provided an overall structure for data collection for all four projects and improving reliability (Beverland \& Lindgreen 2010). An interview guide was used as an important research instrument as the questions reflected the categories from the analytical model. However, complementary questions and follow-up questions were also asked in order to avoid reliance on too restrictive interpretations based only on our predetermined categories (Patton 2002). The interviews lasted between 30 minutes and two and a half hours, and were recorded, transcribed and documented in a case study database. After the interviews were completed, a workshop with the key respondents served as an important forum to check our early interpretations and increase the validity of the study (Gibbert, et al. 2008). The workshop was designed to be interactive: ten R\&D and purchasing professionals discussed their views on problems in previous and ongoing NPD projects with external suppliers. Therefore, the workshop provided an opportunity to gather new information as well as to verify tentative findings and results (Yin 2009). 
IMM Manuscript 13-158RR

Table 1 - Overview of the interviews

\begin{tabular}{|c|c|c|c|c|}
\hline & Battery project & Storage project & Cable project & Hybrid project \\
\hline \multirow{8}{*}{$\begin{array}{l}\text { Interviews } \\
\text { at Voltcomp }\end{array}$} & Project Manager & Project Manager & Project Manager & Project Manager \\
\hline & R\&D Manager & R\&D Manager & R\&D Manager & R\&D Manager \\
\hline & Business Development & Supply Manager & Sales Representative & Supply Manager \\
\hline & Manager & Senior Vice President & Process Engineer & General Manager \\
\hline & Technical Manager & Manager Marketing and & Technical Specialist & \\
\hline & & Sales & Technical Specialist & \\
\hline & & Communication Manager & & \\
\hline & & Regional Sales Manager & & \\
\hline \multirow{8}{*}{$\begin{array}{l}\text { Interviews } \\
\text { at the } \\
\text { suppliers }\end{array}$} & n.a. & Project Manager & Technical Specialist & Key Account \\
\hline & & & Product Manager & Manager \\
\hline & & & Project Manager & Project Manager \\
\hline & & & & $\begin{array}{l}\text { Application } \\
\text { Enoineer }\end{array}$ \\
\hline & & & & Development \\
\hline & & & & Engineer \\
\hline & & & & Product Manager \\
\hline & $5 \mathrm{~h}$ & $9 \mathrm{~h}$ & $10 \mathrm{~h} 10 \mathrm{~min}$ & Business Engineer \\
\hline
\end{tabular}

Data analysis started with the preparation of individual case study reports for each of the projects. These contained detailed case descriptions including within-case analysis (Eisenhardt 1989; Yin 2009). Key informants were offered the opportunity to review interview transcripts and case study reports and provide feedback (Riege 2003). Data analysis continued with a crosscase analysis (Eisenhardt 1991) of the four cases. Our data was coded into two sets of constructs. The first set consisted of TCE constructs, including transactional and relational mechanisms. These constructs were inspired by a review of TCE literature (David \& Han 2004), and were adapted from David \& Han (2004), Griffith, et al. (2009) and Cox (1996). The second set of constructs was related to the role of purchasing and was adapted from the measurements used by Nijssen, et al. (2002) (see Appendix A). The data coding was consistent across the cases. The projects were dynamic and evolved during the development process, but the characteristics described are those that were dominant in the collaboration between Voltcomp and its suppliers. 
The data analysis was guided by finding within-group similarities and differences (Eisenhardt 1989). The analysis was partly conducted during the data collection, as suggested by Miles \& Huberman (1984). In order to systematically analyze the data, we conducted content analysis (Weber 1996) and used the principle of chain of evidence (Yin 2009) where tentative findings were presented at the workshop. Also, by having several viewpoints, both external (the buying

firm and the suppliers) and internal (mainly R\&D, project management and purchasing) views of the projects, we were able to verify information and find contradictions in explanations about governance. By addressing additional rival explanations, internal validity was strengthened. The study of the fourth project with a lower degree of uncertainty made it possible to determine whether the governance practices were varying with technological uncertainty, or just common practice disregarding the degree of technological uncertainty. Validity was also strengthened by theory triangulation, which enabled us to verify our findings by adopting multiple perspectives (Yin 2009) and guided data gathering and analysis (Gibbert, et al. 2008). Finally, reliability was strengthened by case study protocols and a case study database which was used to store all the collected data (Yin 2009).

\section{The four projects}

Voltcomp is the market leader in the area of products in power and automation. The firm has more than 100,000 employees and a worldwide presence. Purchasing is divided into strategic and operational purchasing. There is no policy that prescribes purchasing's inclusion in NPD; however, there are guidelines that stress the importance of strategic purchasing's involvement in collaborative NPD where suppliers are included. Collaborative NPD projects have similar structures and processes regardless of their relation to a specific division or unit at Voltcomp. 
The four projects were relatively small; each had fewer than ten members on the project team. The battery, storage and cable projects were NPD projects that involved new technology that needed development to manage the high-voltage applications of the newly developed products. In contrast, the hybrid project was an NPD project that implemented technology that had been used previously in similar products, but not in the industry in question or at Voltcomp. The four suppliers that were involved in the projects were large firms that were market leaders in their respective fields. The duration of the projects varied from one to eight years (Table 2).

Table 2 - Case overview

\begin{tabular}{lllll}
\hline & Battery project & Storage project & Cable project & Hybrid project \\
\hline Supplier's number of employees & 3,000 & 4,100 & 5,100 & 46,000 \\
Supplier's main industry & Battery & Battery & Plastic material & Bearing \\
Project duration & 8 years & 3 years & 4 years & 1 year \\
Unit at Voltcomp & Power & Power & Transmission & Motor \\
\hline
\end{tabular}

\subsection{Battery project}

The battery project aimed to develop a battery for high-voltage applications. There was no existing battery that was suitable for this application. Therefore, Voltcomp needed to involve a supplier for the development of the battery. The application is a part of Voltcomp's most important products and in an area in which they are experts. The NPD project team consisted of individuals from the R\&D department. Technological uncertainties included future technology development, competing technologies, performance and whether the desired voltage could be achieved. This was Voltcomp's first collaboration with this supplier. The battery was developed for Voltcomp with no alternative use. The development of specific infrastructure and monitoring systems that was particularly designed for this application was part of the project. Although the battery would be owned by the supplier, Voltcomp could patent technology and ideas 
IMM Manuscript 13-158RR

surrounding the battery. During the project, intellectual property (IP) discussions were handled by the project manager. Voltcomp and the supplier had non-disclosure agreements (NDAs) but did not develop a formal contract for the collaboration until the end of the project. Patent discussions were enabled by the project manager and the R\&D organization. Trust and goal alignment were enabled by the project manager, who had most contact with the supplier. In addition, several R\&D engineers were also involved in creating trust.

During the project, the firms worked separately and solved problems by themselves. The firms shared limited information and there was a lack of understanding of the goal of the project. Voltcomp aimed to develop a battery for high-voltage applications, while the supplier made little effort in development, hoping that their battery would fit the application with minor modifications. Hence, the supplier demonstrated limited commitment to the project. After almost eight years of collaboration, Voltcomp decided to formulate a more extensive contract with the supplier. This proved to be problematic for the project team, who contacted purchasing and asked for help with the contract. The project manager described the situation when purchasing got involved as follows:

It was in the end when we wanted to formalize the collaboration that the purchasing management got involved. We went to visit the supplier with a lot of documents on what our requirements were. They had no understanding of it.

In the end, the parties did not agree on any contracts and no contract was ever signed. Instead, the project was terminated without having developed a functioning battery for highvoltage applications.

Throughout large parts of the battery project, $R \& D$ engineers and the project manager took care of relational governance issues related to the relationship. Purchasing had a more limited 
role, but was involved towards the end of the project to solve contractual problems, i.e. transactional governance. It seems that organizational separation was used as a strategy to incur transactional governance in a project where the success of relational governance was doubtful. What may have been important was that Voltcomp and the supplier had no prior history of collaboration, and it turned out to be difficult to establish goal alignment in the project team.

Based on this project alone we cannot develop firm conclusions on our preliminary observation of organizational separation. The project might as well just be an example of inadequate management. Therefore, it needs to be determined whether or not organizational separation is more widely used as a practice to achieve complementarity of transactional and relational governance. The storage and cable projects serve as evidence of more successful collaborations in technologically uncertain projects and are discussed in the following sections.

\subsection{Storage project}

Similar to the battery project, the storage project's aim was to develop a battery for high-voltage applications. Such a battery is not available on the market yet. Thus the development included a lot of research and testing of the battery cell. There were a number of technological uncertainties in the project, many involving the difficulties with high voltage and the effects on the battery function. The resulting product included many specific adjustments in order for the storage the fit. Therefore, the product could only be used in this version of Voltcomp's system. The project was very important to Voltcomp as the product is part of Voltcomp's core competencies. Consequently, progress was reported directly to the highest management. Purchasing was responsible for selecting the supplier but was not a part of the project team. The supplier had 
IMM Manuscript 13-158RR

been previously involved in projects at another part of Voltcomp, but the project team had no prior experience with the supplier.

At the outset of the project, Voltcomp had the intention of formulating a contract with the supplier to specify responsibilities, IP and who would own new ideas that had been developed. But as the project progressed, Voltcomp decided not to formalize the collaboration with the supplier in a contract. A manager explained the difficulties with formulating a contract:

We decided not to write a contract with the supplier [...] It was a strategic choice. From the beginning we had planned to have a contract about the interface and ownership issues. [...] In the end we didn't write any contract because we felt that no matter what we do it will not be possible to prove who had had which idea.

Voltcomp and the supplier organized joint workshops to discuss problems and ideas. They also had a clear goal in the project, which was shared by the individuals involved. Some information was shared in the project, but the project members expressed a fear of knowledge spillover and potential loss of IP. Therefore, not all technical details about the surrounding parts and the overall system were disclosed. Trust and goal alignment were enabled by the project team, as they had most contact with the supplier. Purchasing was not at all involved in technical discussions, but received the responsibility for IP discussions, especially when both parties claimed to have the ownership of an idea. As there was no written agreement, it was not specified who could patent ideas that had been co-developed. This resulted in several minor conflicts between the firms. The outcome of the project was a battery for high-voltage applications that was installed in a pilot system. 
IMM Manuscript 13-158RR

\subsection{Cable project}

The cable project originated from the power transmissions market's need for better cables to transport electricity. Due to the building of, for example, wind farms at sea, there is a need for high-voltage cables that can transport electricity over long distances. Since this project was at the forefront of what it is possible to do with the present cable material, there were many technical challenges. One aspect was that the material could behave in one way when tested in small-scale laboratory settings and in another way when tested on large-scale production settings. The product was part of Voltcomp's long-term strategies in a field where they are leading experts. Therefore, the cable project is very important for Voltcomp, and its top management received direct progress reports from the project team. The cable was designed specifically for Voltcomp's system and has limited use outside of this application.

The project was carried out in collaboration between Voltcomp and a supplier with whom Voltcomp had collaborated with for decades. The project was organized in teams at Voltcomp and the supplier, and consisted of project managers and technical experts. Many of these individuals knew each other from previous collaborations. Also, the project had a steering board with three individuals from each firm. The steering board made strategic decisions, handled problems related to contracts, IP, commercialization, time plan adjustments and similar issues. The project team members of both firms collaborated closely and solved daily technical issues by continuous communication and larger technical problems by in-depth discussions in specific workshops. Purchasing was not involved in the development project, but it was agreed that they would handle price negotiations with the supplier once the product needed to be produced.

During the NPD project, there were only tentative price discussions between Voltcomp and the supplier. The R\&D manager explained purchasing's absence in the cable project: 
IMM Manuscript 13-158RR

We feel that at this point they (purchasing) would not contribute with anything worthwhile.

This is a project with technology focus.

The project members described the collaboration as characterized by a friendly atmosphere. Both project teams agreed on the goal of the project, and as IP and commercial issues were handled outside the project teams, there were very few conflicts. The relationship with this particular supplier has endured for decades and individuals in the project know each other very well.

The project resulted in a cable for high-voltage applications with better characteristics than the existing cable. However, the specific aim of reduction in losses in the transportation was not met, and thus the project continued after termination with a new project that aimed to develop a new generation of cables.

Also in this project, $R \& D$ engineers and project managers had in important role in relational governance. However, transactional governance was also enabled by R\&D, i.e. by the project steering board. This steering board consisted of technical managers and the project managers. Contractual agreements between the firms were discussed and decided upon by the steering board. Besides the project managers, the $R \& D$ engineers were not involved at all in this transactional governance. Further, purchasing was viewed as purely operational and was responsible for price negotiations once the NPD project was terminated and the product was finalized. Hence, purchasing had no ability to influence contracts, exclusivity periods or the relationship with the supplier during the project. In addition, also trust and goal alignment was enabled through the steering board and the project team, who had years of previous experience with the supplier and had collaborated closely during the NPD project.

The battery, the storage and the cable projects provide consistent empirical evidence on the limited role of purchasing and organizational separation of transactional and relational 
IMM Manuscript 13-158RR

governance in technologically uncertain projects. However, it may be questioned whether organizational separation was a deliberate strategy or just common practice for all projects at Voltcomp. Although Voltcomp argues that its purchasing function is strategic and they have been encouraged to involve purchasing R\&D projects, it might be that purchasing's absence in the projects and its decoupled role is just symptomatic of a lack of internal integration at Voltcomp. In order to establish whether organizational separation was used deliberately or was just due to inaccurate internal integration practices, an additional project was studied with different characteristics. The hybrid project is characterized by considerably lower technological uncertainty, represents a lower degree of asset specificity and involved collaboration with a supplier that was previously well-known to Voltcomp.

\subsection{Hybrid project}

The hybrid project aimed to develop a range of hybrid bearings for motors used in the railway industry. Voltcomp needed to solve one of the most serious flaws with the motor, i.e. the possibility of electric current going through the bearing and causing the motor to fail. The new bearing could solve this potential problem. The technological uncertainties related to this technology were few and limited, as a similar solution had been tested and implemented with satisfying results in other products at other firms. The developed item was modular and was intended to be sold and implemented in other motor manufacturers' products.

Voltcomp has collaborated with the supplier for almost a hundred years and the firms are well aware of each other's organization and structure. The project team at Voltcomp consisted of engineers from the R\&D department and the purchasing manager. At the beginning of the project, the parties had formulated a contract, specifying non-disclosure agreements (NDAs), 
exclusivities, IP and price forecasts. Also, it was agreed that the developed products belonged to the supplier and that no exclusivity period for Voltcomp would apply. Voltcomp had a clear interest in this bearing the new standard solution in the whole industry. Hence, potential patenting that did not concern the motor per se belonged to the supplier. The efforts of Voltcomp were far-stretching as Voltcomp even supported the supplier in launching the product on a wider market in order to promote the new bearing design on this market.

Purchasing involvement in the hybrid project was not limited to contractual issues. Instead, purchasing had an active role during technical meetings. Consequently, purchasing enabled both transactional and relational governance. Contracts were enabled through the purchasing manager while patent discussions were handled in collaboration between $\mathrm{R} \& \mathrm{D}$ and purchasing. Moreover, purchasing was involved throughout the NPD project as a member of the project team and was viewed as an important contributor by both Voltcomp and the supplier.

Most development efforts were carried out by the supplier. However, these efforts were largely guided by Voltcomp's input on the characteristics and behavior of the motor. The project teams from Voltcomp and the supplier met every six weeks to discuss progress and problems that had arisen. One particular challenge was to balance technical development while also controlling the cost of the developed product. The technical manager at Voltcomp commented on this balance:

Don't mix up business and collaboration. You need to be both friends and enemies in the right situation. We are enemies when prices are discussed and friends when we discuss technology.

The firms shared information on technology and market without restrictions. This was possible as the technology was already protected in patents. Voltcomp and the supplier shared 
the same goal for the project; the outcome of the product was to be launched at the world's biggest railway fair.

The hybrid project shows that purchasing's role in this project with less technological uncertainty differs considerably from the projects with higher technological uncertainty. Rather than organizational separation, this project is organized so that transactional and relational governance are performed in an integrated manner.

\subsection{Cross-case comparison}

The analytical interpretation of the empirical observations is based on systematic comparisons of the four projects along several of the key dimensions of TCE (Table 3). In particular, in relation to the level of integration along several dimensions, and in line with research proposition 1 , it seems that the projects build on combinations of high and low levels of integration. Table 3 shows an empirical pattern of organizational separation at Voltcomp, at least in the three projects characterized by a high degree of uncertainty. In these projects, the level of integration between R\&D and purchasing was low, while at the same time the level of integration between the supplier and Voltcomp was relatively high. 
IMM Manuscript 13-158RR

Table 3 - TCE: Cross-case summary

\begin{tabular}{|c|c|c|c|c|}
\hline \multirow{2}{*}{\multicolumn{2}{|c|}{$\begin{array}{ll} & \text { Battery project } \\
\text { Asset specificity } & \end{array}$}} & \multirow[t]{2}{*}{ Storage project } & \multirow[t]{2}{*}{ Cable project } & \multirow[t]{2}{*}{ Hybrid project } \\
\hline & & & & \\
\hline $\begin{array}{l}\text { Relationship-specific } \\
\text { investment }\end{array}$ & High & High & High & Low \\
\hline Degree of modularity & Low & Low & Low & High \\
\hline Strategic value & High & High & High & Low \\
\hline Technology specificity & High & High & High & Low \\
\hline Core competencies & High & High & High & Low \\
\hline Uncertainty & & & & \\
\hline Technological & High & High & High & Low \\
\hline Frequency & & & & \\
\hline Prior history & No prior history & $\begin{array}{c}\text { One previous NPD } \\
\text { project }\end{array}$ & $\begin{array}{l}\text { Decades of NPD } \\
\text { collaboration }\end{array}$ & $\begin{array}{c}\text { Decades of } \\
\text { supplying items }\end{array}$ \\
\hline Level of integration & & & & \\
\hline $\begin{array}{l}\text { R\&D-purchasing } \\
\text { communication (intra) }\end{array}$ & Low & Low & Low & High \\
\hline $\begin{array}{l}\text { Buyer-supplier } \\
\text { communication (inter) }\end{array}$ & Medium & High & High & High \\
\hline $\begin{array}{l}\text { Problem-solving } \\
\text { (inter) }\end{array}$ & Mostly separated & Some integration & Heavily integrated & Integrated \\
\hline $\begin{array}{l}\text { Information-sharing } \\
\text { (inter) }\end{array}$ & $\begin{array}{l}\text { Narrow and deep, } \\
\text { mostly one- } \\
\text { directional }\end{array}$ & $\begin{array}{l}\text { Broad but shallow } \\
\text { multi-directional }\end{array}$ & $\begin{array}{l}\text { Narrow and deep } \\
\text { multi-directional }\end{array}$ & $\begin{array}{l}\text { Broad and deep } \\
\text { multi-directional }\end{array}$ \\
\hline
\end{tabular}

The combination of low and high levels of integration in projects with a high degree of uncertainty can be further explored by a systematic overview of the organizational responsibilities related to the deployment of transactional and relational mechanisms. Table 4 shows that transactional governance is largely performed outside the project team. Instead, project managers, purchasing managers and the projects' steering board fulfill an important role in transactional activities. Further, relational governance is carried out by the project team members, the project manager, and to some extent also the project steering board. Purchasing is only involved in relational governance in the hybrid project, the project with considerable lower uncertainty and asset specificity. Consequently, the overview of the empirical observations in table 3 and 4 indicate that transactional and relational governance can be used to achieve simultaneously limited and extensive levels of collaboration between different actors at the 
customer and supplier firms, in line with proposition 2. However, also within the mode of relational governance, within the project team, the R\&D engineers and project managers deliberately delimit the area of extensive collaboration to issues specifically related to the component of the supplier and minimizing extensive communication and collaboration on the surrounding systems. Further, the observations extend proposition 3 by not only showing that purchasing and R\&D fulfill a complementary role in achieving transactional and relational governance, but also pointing at a strategy of organizational separation of transactional and relational governance activities in highly uncertain projects by deliberately locating transactional governance outside the project team.

Table 4 - Enabling of transactional and relational mechanisms

\begin{tabular}{|c|c|c|c|c|}
\hline & Battery project & Storage project & Cable project & Hybrid project \\
\hline \multicolumn{5}{|l|}{$\begin{array}{l}\text { Transactional } \\
\text { mechanisms }\end{array}$} \\
\hline Contracts & $\begin{array}{l}\mathrm{R} \& \mathrm{D} \text { (project manager) } \\
\text { and purchasing manager }\end{array}$ & $\begin{array}{l}\text { Purchasing } \\
\text { manager }\end{array}$ & R\&D (steering board) & Purchasing manager \\
\hline $\begin{array}{l}\text { Patent } \\
\text { discussions }\end{array}$ & R\&D (project manager) & $\begin{array}{l}\text { Purchasing } \\
\text { manager }\end{array}$ & R\&D (steering board) & $\begin{array}{l}\text { R\&D and purchasing } \\
\text { manager }\end{array}$ \\
\hline $\begin{array}{l}\text { Specific } \\
\text { investments }\end{array}$ & R\&D (project manager) & $\begin{array}{l}\text { R\&D (project } \\
\text { manager) }\end{array}$ & R\&D (steering board) & $\begin{array}{l}\text { R\&D and purchasing } \\
\text { manager }\end{array}$ \\
\hline \multicolumn{5}{|l|}{$\begin{array}{l}\text { Relational } \\
\text { mechanisms }\end{array}$} \\
\hline Trust & $\begin{array}{l}\text { R\&D (project manager } \\
\text { and to some extent the } \\
\text { project team) }\end{array}$ & $\begin{array}{l}\mathrm{R} \& \mathrm{D} \text { (project } \\
\text { team) }\end{array}$ & $\begin{array}{l}\text { R\&D (steering board } \\
\text { and project team) }\end{array}$ & $\begin{array}{l}\text { R\&D and purchasing } \\
\text { manager }\end{array}$ \\
\hline Goal alignment & R\&D (project manager) & $\begin{array}{l}\text { R\&D (project } \\
\text { manager) }\end{array}$ & $\begin{array}{l}\text { R\&D (steering board } \\
\text { and project team) }\end{array}$ & $\begin{array}{l}\text { R\&D and purchasing } \\
\text { manager }\end{array}$ \\
\hline Relational norms & R\&D (project manager) & $\begin{array}{l}\text { R\&D (project } \\
\text { manager) }\end{array}$ & $\begin{array}{l}\mathrm{R} \& \mathrm{D} \text { (steering board } \\
\text { and project team) }\end{array}$ & $\begin{array}{l}\text { R\&D and purchasing } \\
\text { manager }\end{array}$ \\
\hline $\begin{array}{l}\text { Frequent } \\
\text { transactions }\end{array}$ & No previous transactions & $\mathrm{R} \& \mathrm{D}$ & $\mathrm{R} \& \mathrm{D}$ & $\begin{array}{l}\text { R\&D and purchasing } \\
\text { manager }\end{array}$ \\
\hline
\end{tabular}


IMM Manuscript 13-158RR

\section{Analysis}

\subsection{Governance in collaborative NPD projects}

The study reveals several interesting issues related to the attributes of the transactions. In particular, contract negotiation activities in relation to the NPD work were more limited than expected. In the projects with high technological uncertainty, detailed contracts were not used at all, but were rather based on general and non-specific agreements. In line with previous research stressing the limits of contracts (Griffith, et al. 2009), this study confirms the limited role of contracts in governing collaborative activities in projects. Although contract negotiations did occur in the project with lower technological uncertainty, these negotiations considered future price and volume discussions and were thus focused on ex ante governance of transactions during production phases rather than development phases. Rather than detailed contracts, generally formulated non-disclosure agreements seemed to have been important in safeguarding the risk for opportunistic behavior. Several engineers stressed that as long as there was an NDA, they were prepared to collaborate as though supplier engineers were internal colleagues.

However, the fear of knowledge spillover was also prevalent. In the battery and storage projects this was managed through limited sharing of information and limited joint problem-solving. Here, the importance of prior history may play a role. Previous experiences in the cable and hybrid projects may have created relational norms and trust that are helpful in dealing with the safeguarding problem (Heide \& John 1990; Mahapatra, et al. 2010). In these projects the firms tended to put less effort into transactional governance mechanisms, particularly into contracts (Yu, et al. 2006).

Governance related to measurement problems and adaptability problems were taken care of by increasing the degree of integration, i.e. not an either-or decision between market governance 
and hierarchical solutions (David \& Han 2004) but a hybrid form guided by relational mechanisms such as goal alignment, trust and relational norms, and based on limited commitments in the relationship (Rindfleisch \& Heide 1997). Measurement problems were dealt with through meetings, joint testing, phone conferences and email conversations between Voltcomp and its suppliers. Contradicting to expectations that reduced levels of uncertainty would reduce difficulties related to compliance, and thus be associated with lower degrees of integration; in the hybrid project in particular, problem-solving was integrated and based on broad as well as deep multidirectional information-sharing. Perhaps rather than being driven by measurement problems, this integrated way of working was driven by the shared desire of Voltcomp and the supplier to make the bearing the new standard solution in the industry. In addition, the integrated way of working was reinforced by the firms' extensive previous experiences with each other. Thus, as the firms were not constrained by severe safeguarding difficulties (clear IP arrangements) and faced limited adaptability problems (low uncertainty), it was possible to intensify information-sharing. These same conditions were not present in the projects with higher technological uncertainty, more severe safeguarding and critical adaptability challenges. Here, trade-offs were made through limiting information-sharing and commitment and increased possibilities for measurement through more information-sharing. In the cable project, previous experience seems to have been an important mediator and allowed for higher degrees of information-sharing and integration. Table 5 gives an overview of the TCE problems and responses in high technological uncertainty and low technological uncertainty projects. 
IMM Manuscript 13-158RR

Table 5 - TCE problems: Contracting, safeguarding, measurement and adaptation

\begin{tabular}{|c|c|c|}
\hline & $\begin{array}{l}\text { High technological uncertainty } \\
\text { projects }\end{array}$ & Low technological uncertainty project \\
\hline $\begin{array}{l}\text { Contract negotiation and } \\
\text { writing }\end{array}$ & $\begin{array}{l}\text { Lengthy negotiations but no } \\
\text { agreement on contract } \\
\text { - } \quad \text { o use of contracts } \\
\text { - Use of previously developed } \\
\text { agreement, general and non- } \\
\text { specific }\end{array}$ & $\begin{array}{l}\text { - Negotiations mainly concerened } \\
\text { future price and volume } \\
\text { development }\end{array}$ \\
\hline Safeguarding specific assets & $\begin{array}{ll}\text { - } & \text { Limited sharing of information } \\
\text { - } & \text { Fear of knowledge spillover } \\
\text { - } & \text { Limited problem-solving } \\
\text { - } & \text { Relying on NDA and trust }\end{array}$ & $\begin{array}{l}\text { - Limited safeguarding, relying on IP } \\
\text { and NDA }\end{array}$ \\
\hline $\begin{array}{l}\text { Adaptation problem due to } \\
\text { technological uncertainty }\end{array}$ & $\begin{array}{l}\text { - } \quad \text { Limited commitment to supplier } \\
\text { - } \quad \text { Exploring multiple technologies }\end{array}$ & $\begin{array}{l}\text { Limited commitment (contractual } \\
\text { length) }\end{array}$ \\
\hline Measurement problem & $\begin{array}{ll}\text { - } & \text { Increased integration } \\
\text { - } & \text { Increased information-sharing }\end{array}$ & - $\quad$ Common interest \\
\hline
\end{tabular}

\subsection{Organizational separation and complementarity}

The studied projects used both transactional and relational mechanisms to govern the collaborations. This is similar to previous studies, which show that transactional and relational governance complement each other (Arranz \& de Arroyabe 2012; Blomqvist, et al. 2005; Gulati 1995; Melander, et al. 2014). Much of the relational governance took place within the R\&D project team and involved the project manager, especially in the projects with high technological uncertainty. Relational issues were predominantly enabled within the project team and by the project manager. This might not be surprising, as the literature highlights the importance of having clear goals and discussing the project's aims within the project group (Dayan \& Basarir 2009). After all, the project members are responsible for developing the products. Similar to goal alignment, relational norms were managed by $R \& D$, which has the majority of the contacts with the supplier and thus is interested in motivating suppliers to behave in ways that preserve the relationship (Jap \& Ganesan 2000) and build a solid ground for collaborative development efforts. 
IMM Manuscript 13-158RR

The $R \& D$ project team and project manager did not take a prevalent role in transactional governance. Rather, transactional issues were taken care of by purchasing and to some extent the project steering board, especially in the project with a high degree of uncertainty. In these projects we found clear indications of organizational separation of transactional and relational responsibilities. Contracts were not formulated, nor were they managed within the project organization. Instead, it was either the purchasing manager or the steering board that handled transaction-related issues such as NDAs and exclusivity agreements. A similar pattern of organizational separation, although not as clear, was revealed for patent discussions. Similarly to contracting, patent discussions in the storage and cable projects were facilitated by the purchasing manager and the steering board respectively. Only in the battery project did patent discussions take place within the project organization through the project manager, who belonged to the R\&D department at the firm. Considering the lack of success of the project, this might not have been a successful approach. Patent discussions in the hybrid project were instigated as a concerted effort by R\&D and purchasing.

Our study demonstrates that purchasing's role in NPD developments with high assetspecificity and high technological uncertainty requires further attention. Although purchasing at Voltcomp claims to be strategic, and is encouraged to take part in collaborative NPD projects with suppliers, not all R\&D departments view purchasing as strategic in situations of technological uncertainty. Previous studies have highlighted similar disagreements in how purchasing is viewed (Tassabehji \& Moorhouse 2008). While an overwhelming amount of research points to the importance of involving purchasing in collaborative NPD with suppliers (Birou \& Fawcett 1994; Cousins, et al. 2006; Luzzini \& Ronchi 2011; Schiele 2006; Walter 
IMM Manuscript 13-158RR

2003), there are indications that for projects with high technological uncertainty, purchasing's influence may be limited (Un, et al. 2010).

In the projects with high asset specificity and high technological uncertainty, close contact with the suppliers as well as relational mechanisms were enabled by $R \& D$, either through the project manager, the project team or the steering board. Aspects of trust in buyer-supplier relationships, such as consistency, competence and openness (Adler 2001) were enabled through the R\&D organization. By including some of the same individuals from previous collaborations, the firm ensured consistency. Further, by separating commercial discussions from the project team, the teams could have a high degree of openness in their technical discussions without being hindered by commercial negotiations. Hence, it seems that transactional issues were handled outside of the development team in order to avoid signals of distrust (Brattström and Richtnér 2013; Jap \& Ganesan 2000). Consequently, organizational separation may be a way to handle the trade-offs between responses related to safeguarding and adaptability that point to less integration and solutions to measurement problems that demand more information-sharing, as described in research proposition 1. Organizational separation was not prevalent in the project with lower technological uncertainty. This points at two important issues: First, we could determine that organizational separation of purchasing and engineering is neither common practice for all type of NPD projects at Voltcomp, nor an indication of poor internal integration practices. This strengthens our finding of organizational separation as an important approach for achieving complementarity of transactional and relational governance under circumstances of technological uncertainty. This is an important extension of research proposition 2 and 3. Second, in line with our discussion above, safeguarding and adaptability problems might not pose similar challenges in projects with a relatively low degree of uncertainty compared to high- 
IMM Manuscript 13-158RR

uncertainty projects. The need for trade-offs is therefore not particularly prevalent in these projects.

A note needs to be made here on the role of the project steering board. In the theoretical section, the project steering board was not identified as a particularly important actor in the interactions with suppliers. Their role might have been overlooked in previous literature on buyer supplier relationships, as particular project management models and organizational issues are normally not in focus. Alternatively, project steering boards were particularly important in this study due to the strategic importance of the NPD projects. Future research could look further into this.

\section{Conclusions}

With a focus on NPD projects with a high degree of technological uncertainty, this paper set out to gain an understanding of how firms achieve complementarity of transactional and relational governance in collaborative projects with suppliers. Our results confirm earlier findings that transactional and relational governance are used as complementary modes (Blomqvist, et al. 2005; Poppo \& Zenger 2002), and provide suggestions and explanations of how this complementarity is achieved. Following TCE theory, we propose that organizational solutions to achieve complementarity are driven by trade-offs between challenges related to safeguarding, measurement and adaptability. In particular, in technologically uncertain NPD projects, safeguarding, adaptability and measurement issues tend to drive contradictory responses. While the former would warrant limited information-sharing, the latter two demand an increased degree of integration, at least during the NPD project. We propose that organizational separation of transactional and relational mechanisms is used as a way to handle these contradictory demands. 
Safeguarding issues are here connected to the use of transactional mechanisms in collaborative relationships, including contracts, commercial agreements, and patent discussions. These are separated from measurement and adaptability issues by letting an actor outside the R\&D project organization take responsibility. This is a way to avoid distrust, as suggested by Jap \& Ganesan (2000) and recently also by Brattström \& Richtnér (2013), and to avoid distortion of relational rents that represent the benefits that are jointly generated in an exchange relationship (Dyer \& Singh 1998). Organizational separation allows project teams to focus on technical issues, and take care of adaptability requirements and measurement difficulties. Depending highly on relational governance and mechanisms such as trust, goal alignment, relational norms and previous transactions, the $\mathrm{R} \& \mathrm{D}$ organization, rather than purchasing, can work closely with the supplier's engineers. Our study suggests that previous collaborative experiences facilitate this highly integrated way of working.

Our findings suggest that organizational separation is used as a deliberate strategy to achieve complementarity of transactional and relational governance, and has implications for the role of purchasing in collaborative NPD projects with suppliers. In technologically uncertain projects, purchasing's role seems to be limited to transactional issues. This contrasts with previous studies that have suggested that purchasing has an increased role in coordinating cross-functional and relational responsibilities in NPD (McGinnis \& Vallopra 1999; Schiele 2010; van Echtelt, et al. 2008). We propose that purchasing enables transactional but not necessarily relational governance with suppliers, at least in situations of technological uncertainty. When technological uncertainty is low, our findings confirm previous research on the role of purchasing. Therefore technological uncertainty must be considered an important factor influencing organizational 
responses to achieve complementarity of transactional and relational governance and the role of purchasing in collaborative NPD projects (Oh \& Rhee 2010).

Our findings have several managerial implications. First, there are no standard routines and procedures that can be devised for all types of collaborative NPD projects. Instead, the NPD project's technological uncertainty must be taken into consideration when decisions are made regarding transactional and relational governance. In NPD projects with a higher degree of uncertainty, organizational separation can be a fruitful strategy in order to achieve the right balance between the contradictory demands to protect the organization from opportunistic behavior and at the same time create opportunities for dynamic changes that are necessary due to uncertainty. Second, purchasing is not necessarily evolving into an ever-important function that is taking care of more and more tasks related to supplier involvement in NPD. Instead, purchasing's role sometimes needs to be more limited to focus on dealing with transactional issues (Melander \& Tell 2014). This variability in the role of purchasing requires established cross-functional integration routines to make sure that $R \& D$ and purchasing can devise deliberate strategies at the start of the NPD project.

Although our study reveals clear patterns of organizational separation of transactional and relational governance, our findings are limited by our research methodology. The study of four projects at one firm does not make it possible to generalize the findings to a larger population. The analytical generalizations and propositions that can be derived thus warrant further studies with quantitative designs. TCE theory has been used as the basis for our conclusions and provided a fruitful avenue for our research. However, other theoretical perspectives on, for instance, power-dependence (LaBahn \& Krapfel 2000) or knowledge integration, could reveal additional solutions to the balance of transactional and relational issues. Future studies need to 
IMM Manuscript 13-158RR

continue investigating governance and internal division of responsibilities in collaborative NPD projects with technological uncertainty involving suppliers. 


\section{IMM Manuscript 13-158RR}

\section{References}

Adler, P.S. (2001). Market, hierarchy, and trust: the knowledge economy and the future of capitalism. Organization Science, 12 (2), 215-234.

Argyres, N. and Mayer, K.J. (2007). Contract design as a firm capability: an integration of learning and transaction cost perspectives. Academy of management review, 32 (4), 1060-1077.

Arranz, N. \& de Arroyabe, J. C. Fdez (2012). Effect of formal contracts, relational norms and trust on performance of joint research and development projects. British Journal of Management, 23 (4), 575-588.

Baldwin, C.Y. (2008). Where do transactions come from? Modularity, transactions, and the boundaries of firms. Industrial and Corporate Change, 17 (1), 155-195.

Bensaou, M (1999). Portfolios of buyer-supplier relationships. Sloan management review, 40 (4), 35-44.

Beverland, M. \& Lindgreen, A. (2010). What makes a good case study? A positivist review of qualitative case research published in Industrial Marketing Management, 1971-2006. Industrial Marketing Management, 39 (1), 56-63.

Birou, L.M. \& Fawcett, S.E. (1994). Supplier involvement in integrated product development: a comparison of US and European practices. International Journal of Physical Distribution \& Logistics Management, 24 (5), 4-14.

Blomqvist, K., Hurmelinna, P., \& Seppanen, R. (2005). Playing the collaboration game right — balancing trust and contracting. Technovation, 25 (5), 497-504.

Brattström, A. \& Richtnér, A. (2013). Good Cop-Bad Cop: Trust, Control, and the Lure of Integration. Journal of Product Innovation Management, 31 (3), 1-15.

Brown, S.L. \& Eisenhardt, K.M. (1995). Product development: past research, present findings, and future directions. The Academy of Management Review, 20 (2), 343-378.

Burkert, M., Ivens, B.S., \& Shan, J. (2012). Governance mechanisms in domestic and international buyersupplier relationships: an empirical study. Industrial Marketing Management, 41 (3), 544-556.

Burt, D.N. \& Soukup, W.R. (1985). Purchasing's role in new product development. Harvard Business Review, $63(5), 90-97$.

Cannon, J.P., Achrol, R.S., \& Gundlach, G.T. (2000). Contracts, norms, and plural form governance. Journal of the Academy of Marketing Science, 28 (2), 180-194.

Claro, D.P., Hagelaar, G., \& Omta, O. (2003). The determinants of relational governance and performance: how to manage business relationships?. Industrial Marketing Management, 32 (8), 703-716.

Cousins, P.D., Lawson, B., \& Squire, B. (2006). An empirical taxonomy of purchasing functions. International Journal of Operations \& Production Management, 26 (7), 775-794.

Cox, A. (1996). Relational competence and strategic procurement management: towards an entrepreneurial and contractual theory of the firm. European Journal of Purchasing \& Supply Management, 2 (1), 57-70.

David, R.J. \& Han, S-K. (2004). A systematic assessment of the empirical support for transaction cost economics. Strategic Management Journal, 25 (1), 39-58.

Dayan, M. \& Basarir, A. (2009). Antecedents and consequences of team reflexivity in new product development projects. Journal of Business \& Industrial Marketing, 25 (1), 18-29.

Dyer, J.H. (1997). Effective interim collaboration: how firms minimize transaction costs and maximise transaction value. Strategic Management Journal, 18 (7), 535-556.

Dyer, J.H. \& Singh, H. (1998). The relational view: Cooperative strategy and sources of interorganizational competitive advantage. Academy of Management Review, 23 (4), 660-679.

Eisenhardt, K.M. \& Graebner, M.E. (2007). Theory building from cases: opportunities and challenges, Academy of management journal, 50 (1), 25-32.

Eisenhardt, K.M. (1989). Building theories from case study research, Academy of management review, 14, 4, 532-550.

Eisenhardt, KM. (1991). Better stories and better constructs: the case for rigor and comparative logic. Academy of Management Review, 16 (3), 620-627.

Gibbert, M., Ruigrok, W., \& Wicki, B. (2008). What passes as a rigorous case study?. Strategic Management Journal, 29 (13), 1465-1474.

Granovetter, M. (1985). Economic action and social structure: the problem of embeddedness. American Journal of Sociology, 91 (3), 481-510. 


\section{IMM Manuscript 13-158RR}

Griffith, D.A., Harmancioglu, N., \& Droge, C. (2009). Governance decisions for the offshore outsourcing of new product development in technology intensive markets. Journal of World Business, 44 (3), 217-224.

Gulati, R. (1995). Does familiarity breed trust? The implications of repeated ties for contractual choice in alliances. Academy of management journal, 38 (1), 85-112.

Hagedoorn, J. (2002). Inter-firm R\&D partnerships: an overview of major trends and patterns since 1960. Research Policy, 31 (4), 477-492.

Handfield, R.B. \& Lawson, B. (2007). Integrating suppliers into new product development. ResearchTechnology Management, 50 (5), 44-51.

Heide, J.B. \& John, G. (1990). Alliances in industrial purchasing: the determinants of joint action in buyersupplier relationships. Journal of marketing Research, 27 (1), 24-36.

Heide, J. B \& John, G. (1992). Do norms matter in marketing relationships?. The Journal of Marketing, 56 (2), 32-44.

Håkanson, L. (1993). Managing cooperative research and development: partner selection and contract design. $R \& D$ Management, 23 (4), 273-285.

Jagdev, H.S. \& Thoben, K-D. (2001). Anatomy of enterprise collaborations. Production planning \& control, 12 (5), 437-451.

Jap, S.D. \& Ganesan, S. (2000). Control mechanisms and the relationship life cycle: implications for safeguarding specific investments and developing commitment. Journal of marketing Research, 37 (2), 227-245.

John, G. \& Reve, T. (2010). Transaction cost analysis in marketing: looking back, moving forward. Journal of Retailing, 86 (3), 248-256.

Krishnan, V. \& Bhattacharya, S. (2002). Technology selection and commitment in new product development: the role of uncertainty and design flexibility. Management Science, 48 (3), 313-327.

LaBahn, D.W. \& Krapfel, R. (2000). Early supplier involvement in customer new product development: a contingency model of component supplier intentions. Journal of Business Research, 47 (3), 173-190.

Langerak, F. \& Hultink, E.J. (2008). The effect of new product development acceleration approaches on development speed: a case study. Journal of Engineering and Technology Management, 25 (3), 157-167.

Lau, A.K.W., Tang, E., \& Yam, R. (2010). Effects of supplier and customer integration on product innovation and performance: empirical evidence in Hong Kong manufacturers. Journal of Product Innovation Management, 27 (5), 761-777.

Liu, Y., Luo, Y., \& Liu, T. (2009). Governing buyer-supplier relationships through transactional and relational mechanisms: evidence from China. Journal of Operations Management, 27 (4), 294-309.

Lorenzoni, G. \& Lipparini, A. (1999). The leveraging of interfirm relationships as a distinctive organizational capability: a longitudinal study. Strategic Management Journal, 20 (4), 317-338.

Lumineau, F. \& Henderson, J.E. (2012). The influence of relational experience and contractual governance on the negotiation strategy in buyer-supplier disputes. Journal of Operations Management, 30 (5), 382-395.

Luzzini, D. \& Ronchi, S. (2011). Organizing the purchasing department for innovation. Operations Management Research, 4 (1), 14-27.

Mahapatra, S.K., Narasimhan, R., \& Barbieri, P. (2010). Strategic interdependence, governance effectiveness and supplier performance: a dyadic case study investigation and theory development. Journal of Operations Management, 28 (6), 537-552.

McGinnis, M.A. \& Vallopra, R.M. (1999). Purchasing and supplier involvement: issues and insights regarding new product success. Journal of Supply Chain Management, 35 (3), 4-15.

Melander, L., Rosell, D., \& Lakemond, N. (2014), In pursuit of control: involving suppliers of critical technologies in new product development. Supply Chain Management: An International Journal, 19 (5/6), 722-32.

Melander, L. \& Tell, F. (2014). Uncertainty in collaborative npd: effects on the selection of technology and supplier. Journal of Engineering and Technology Management, 31, 103-119.

Miles, M.B. \& Huberman, A.M. (1984). Qualitative data analysis: a sourcebook of new methods. Sage Publications, Beverly Hills, CA.

Miotti, L. \& Sachwald, F. (2003). Co-operative R\&D: why and with whom?: an integrated framework of analysis. Research Policy, 32 (8), 1481-1499.

Nijssen, E.J., Biemans, W.G., \& De Kort, J.F. (2002). Involving purchasing in new product development. $R \& D$ Management, 32 (4), 281-289. 


\section{IMM Manuscript 13-158RR}

Oh, J. \& Rhee, S.K. (2010). Influences of supplier capabilities and collaboration in new car development on competitive advantage of carmakers. Management Decision, 48 (5), 756-774.

Olausson, D., Magnusson, T., \& Lakemond, N. (2009). Preserving the link between R\&D and manufacturing: exploring challenges related to vertical integration and product/process newness. Journal of Purchasing and Supply Management, 15 (2), 79-88.

Patton, M.Q. (2002). Qualitative research and evaluation methods. (3rd edn.) Sage Publications, Thousand Oaks, CA..

Petersen, K.J., Handfield, R.B., \& Ragatz, G.L. (2003). A model of supplier integration into new product development. Journal of Product Innovation Management, 20 (4), 284-299.

Piekkari, R., Plakoyiannaki, E., \& Welch, C. (2010). Good case research in industrial marketing: insights from research practice. Industrial Marketing Management, 39 (1), 109-117.

Poppo, L. \& Zenger, T. (2002). Do formal contracts and relational governance function as substitutes or complements?. Strategic Management Journal, 23 (8), 707-725.

Poppo, L., Zhou, K.Z., \& Zenger, T.R. (2008). Examining the conditional limits of relational governance: Specialized assets, performance ambiguity, and long-standing ties. Journal of Management Studies, 45 (7), 1195-1216.

Rampersad, G., Quester, P., \& Troshani, I. (2010). Examining network factors: commitment, trust, coordination and harmony. Journal of Business \& Industrial Marketing, 25 (7), 487-500.

Riege, A.M. (2003). Validity and reliability tests in case study research: a literature review with "hands-on" applications for each research phase. Qualitative Market Research: An International Journal, 6 (2), $75-86$.

Rindfleisch, A. \& Heide, J.B. (1997). Transaction cost analysis: past, present, and future applications. Journal of Marketing, 61 (4), 30-54.

Ring, P.S. \& Van De Ven, A.H. (1994). Developmental processes of cooperative interorganizational relationships. Academy of Management Review, 19 (1), 90-118.

Ritter, T. \& Walter, A. (2003). Relationship-specific antecedents of customer involvement in new product development. International Journal of Technology Management, 26 (5), 482-501.

Rosell, D.T., Lakemond, N., \& Wasti, S.N. (2014). Integrating knowledge with suppliers at the R\&Dmanufacturing interface. Journal of Manufacturing Technology Management, 25 (2), 240-257.

Rossetti, C.L. \& Choi, T.Y. (2008). Supply management under high goal incongruence: an empirical examination of disintermediation in the aerospace supply chain. Decision Sciences, 39 (3), 507-540.

Schiele, H. (2010). Early supplier integration: the dual role of purchasing in new product development. $R \& D$ Management, 40 (2), 138-153.

Schiele, H. (2006). How to distinguish innovative suppliers? Identifying innovative suppliers as new task for purchasing. Industrial Marketing Management, 35 (8), 925-935.

Siggelkow, N. (2007). Persuasion with case studies. Academy of Management Journal 50 (1), 20-24.

Tassabehji, R. \& Moorhouse, A. (2008). The changing role of procurement: developing professional effectiveness. Journal of Purchasing and Supply Management, 14 (1), 55-68.

Thomas, E. (2013). Supplier integration in new product development: computer mediated communication, knowledge exchange and buyer performance. Industrial Marketing Management, 42 (6), 890-899.

Un, C.A., Cuervo-Cazurra, A., \& Asakawa, K. (2010). R\&D collaborations and product innovation. Journal of Product Innovation Management, 27 (5), 673-689.

Wagner, S.M. \& Hoegl, M. (2006). Involving suppliers in product development: insights from R\&D directors and project managers. Industrial Marketing Management, 35 (8), 936-943.

Wagner, S.M. (2012). Tapping supplier innovation, Journal of Supply Chain Management, 48 (2), $37-52$.

Walter, A. (2003). Relationship-specific factors influencing supplier involvement in customer new product development. Journal of Business Research, 56 (9), 721-733.

van Echtelt, F.E.A., Wynstra, F., Van Weele, A.J., \& Duysters, G. (2008). Managing supplier involvement in new product development: a multiple-case study. Journal of Product Innovation Management, 25 (2), 180201.

Weber, R.P. (1996). Basic content analysis. Sage Publications, Newbury Park.

Williamson, O. \& Ghani, T. (2012). Transaction cost economics and its uses in marketing. Journal of the Academy of Marketing Science, 40 (1), 74-85.

Williamson, O.E. (1985). The economic intstitutions of capitalism. The Free Press, New York. 


\section{IMM Manuscript 13-158RR}

Wynstra, F., Weggeman, M., \& Van Weele, A. (2003). Exploring purchasing integration in product development. Industrial Marketing Management, 32 (1), 69-83.

Yin, R.K. (2009). Case study research: design and methods. (4th edn.) Sage Publications, Los Angeles, CA.

Yu, C-M.J., Liao, T-J., \& Lin, Z-D. (2006). Formal governance mechanisms, relational governance mechanisms, and transaction-specific investments in supplier-manufacturer relationships. Industrial Marketing Management, 35 (2), 128-139.

Zhou, K.Z., Poppo, L., \& Yang, Z.L. (2008). Relational ties or customized contracts? An examination of alternative governance choices in China. Journal of International Business Studies, 39 (3), 526-534. 
IMM Manuscript 13-158RR

\section{Appendix A: Purchasing constructs}

\begin{tabular}{|c|c|c|c|c|}
\hline Constructs & Battery project & Storage project & Cable project & Hybrid project \\
\hline $\begin{array}{l}\text { Purchasing } \\
\text { managers } \\
\text { participated in the } \\
\text { NPD team }\end{array}$ & $\begin{array}{l}\text { The conclusion is } \\
\text { that we should have } \\
\text { involved purchasing } \\
\text { manager much } \\
\text { earlier. That is the } \\
\text { lesson. We were } \\
\text { happy engineers who } \\
\text { started this project } \\
\text { and we never } \\
\text { thought these } \\
\text { problems could } \\
\text { arise. Project } \\
\text { Manager A }\end{array}$ & $\begin{array}{l}\text { Purchasing had } \\
\text { continuous contact } \\
\text { with the supplier. } \\
\text { Purchasing } \\
\text { Manager A }\end{array}$ & $\begin{array}{l}\text { We feel that at this } \\
\text { point they } \\
\text { (purchasing } \\
\text { management) would } \\
\text { not contribute } \\
\text { anything } \\
\text { worthwhile. This is a } \\
\text { project with } \\
\text { technology focus. } \\
\text { Manager } P\end{array}$ & $\begin{array}{l}\text { It often happened } \\
\text { that engineers } \\
\text { started talking about } \\
\text { one thing and then } \\
\text { moved on to another } \\
\text { without being } \\
\text { finished with the } \\
\text { first issue. That's } \\
\text { when the purchasing } \\
\text { manager said "hold } \\
\text { on, you are not } \\
\text { finished with the } \\
\text { first point." } \\
\text { Manager I }\end{array}$ \\
\hline $\begin{array}{l}\text { Purchasing's } \\
\text { involvement in } \\
\text { supplier selection }\end{array}$ & $\begin{array}{l}\text { Purchasing was not } \\
\text { involved when the } \\
\text { project started, but } \\
\text { became involved at a } \\
\text { later stage. } \\
\text { Purchasing } \\
\text { Manager A }\end{array}$ & $\begin{array}{l}\text { It was my personal } \\
\text { connections with the } \\
\text { supplier that } \\
\text { influenced the } \\
\text { selection of the } \\
\text { supplier. Purchasing } \\
\text { Manager A }\end{array}$ & $\begin{array}{l}\text { I (the technical } \\
\text { expert) visited the } \\
\text { potential suppliers, } \\
\text { taking our } \\
\text { technology. They } \\
\text { presented how far } \\
\text { they had come in } \\
\text { this area. Manager } R\end{array}$ & $\begin{array}{l}\text { The technical } \\
\text { manager and the } \\
\text { purchasing manager } \\
\text { agreed to select the } \\
\text { supplier. Manager } G\end{array}$ \\
\hline $\begin{array}{l}\text { Purchasing } \\
\text { evaluated supplier } \\
\text { performance }\end{array}$ & $\begin{array}{l}\text { Once purchasing got } \\
\text { involved we realized } \\
\text { that it was not } \\
\text { possible to continue } \\
\text { the collaboration. } \\
\text { After several years } \\
\text { of co-development it } \\
\text { was decided that the } \\
\text { collaboration should } \\
\text { end. Purchasing } \\
\text { Manager A }\end{array}$ & $\begin{array}{l}\text { We didn't get any } \\
\text { answers to our } \\
\text { questions. They } \\
\text { didn't answer our } \\
\text { emails and when we } \\
\text { called them to say } \\
\text { that we must receive } \\
\text { help with this, they } \\
\text { told us that they had } \\
\text { a lot to do and } \\
\text { lacked resources. } \\
\text { That's when we } \\
\text { contacted the } \\
\text { purchasing manager, } \\
\text { who also had contact } \\
\text { with the supplier. In } \\
\text { the end his efforts } \\
\text { resulted in a }\end{array}$ & $\begin{array}{l}\text { I (the technical } \\
\text { expert) knew them } \\
\text { (the potential } \\
\text { suppliers): we have a } \\
\text { technology exchange } \\
\text { program so I know } \\
\text { their people, } \\
\text { resources, } \\
\text { developments, } \\
\text { production } \\
\text { capabilities and so } \\
\text { on. [...] We (the } \\
\text { technical expert and } \\
\text { the technology } \\
\text { manager) evaluated } \\
\text { and compared the } \\
\text { suppliers Manager } R\end{array}$ & $\begin{array}{l}\text { You show that both } \\
\text { parties have } \\
\text { delivered something, } \\
\text { that everyone is } \\
\text { doing what they are } \\
\text { supposed to do. } \\
\text { Showing interest and } \\
\text { engagement from } \\
\text { both firms. Clear } \\
\text { about opinions. } \\
\text { There haven't been } \\
\text { expectations that } \\
\text { haven't been } \\
\text { discussed. We have } \\
\text { been clear on what } \\
\text { we want, and so has } \\
\text { the supplier. [...] I } \\
\text { (the purchaser) also }\end{array}$ \\
\hline
\end{tabular}


IMM Manuscript 13-158RR

management

meeting. Project

Manager $B$

Purchasing monitored technological developments

Purchasing was responsible for coordination

Purchasing assisted in the start of production of the new product
The project was technically driven, and a number of engineers from both the buying firm and the supplying firm collaborated. [...] Neither purchasing nor any other function was involved.

Purchasing

Manager A

In the end the purchasing manager got involved when the contract was to be written. In the end the supplier could not guarantee the performance of the batteries. Then they added that they could not promise to deliver the volume that we requested. Project Manager A

[Production never started]
I think this industry is so young that it is difficult to see what will stay and what will disappear. [...] Technical experts follow the development. Manager $F$
I (the technical expert) know them (the potential suppliers). We have many technology meetings (where technology developments are discussed) Manager $R$

A steering board which consists of three members from the buying firm and three members from the supplier has oversight of the collaboration. Project Manager E interface and ownership issues. [...] In the end we didn't write a contract because we felt that no matter what we did it would not be possible to prove who had had which idea.

\section{Manager A}

We can affect their strategy in these meetings (strategic meetings), for instance on their

There are some price discussions [...] This is dealt with outside of the project. It is deal with the supplier in my global purchasing manager role.

Purchasing

Manager B

My (purchasing) role in the project was to monitor cost and prices so that we did not only consider what is best from a technology perspective. [...] Much revolved around getting the supplier to include pros and cons with different ideas from a cost perspective.

Purchasing

Manager B

I (the technical engineer) have handled the technical parts. Every six weeks we have had meetings where all project members were present, including the purchasing manager and the technical manager. The supplier was also present in these meetings. Project Manager D
Don't mix up business and collaboration. You need to be both friends and enemies 
IMM Manuscript 13-158RR

\author{
plans for capacity \\ expansion. \\ Purchasing \\ Manager $A$
}

Purchasing was responsible for communicating changes to the supplier.
It was in the end when we wanted to formalize the collaboration that the purchasing management got involved. We went to visit the supplier with a lot of documents on what our requirements were. They had no understanding of it. It didn't work out. Project Manager A purchasing. So far it has only been a few discussions. Manager $P$

Purchasing is mostly in contact with the supplier's sales and management team [...] Also, patent discussions are handled by purchasing. Project Manager $C$

We (the project managers) have biweekly meetings and check progress. Communication is made when necessary and there is constant managed by

in the right situation.

We are enemies when we discuss prices and friends when we discuss technology.

Manager $G$ where we coordinate communication between project members and between project managers. Almost every day I (the supplier's project manager) discuss something with the buying firm. Project Manager $F$ 